\title{
Engaging disenfranchised urban youth in humanities learning
}

\author{
Diane Wishart \\ djw@ualberta.ca \\ University of Alberta \\ Luis Alberto D'Elia \\ ldelia@ualberta.ca \\ University of Alberta
}

\begin{abstract}
Literature aimed at addressing ways to meet learning needs of disenfranchised students can be enhanced through the addition of case studies. International comparative approaches looking at the specifics of cases can also add to the literature on schooling for disenfranchised students. The purpose of our research was to elicit the perceptions of humanities educators in Spain and in Canada regarding enhancing opportunities to retain disenfranchised students in secondary schools. Our analysis was based on case studies and document analysis. For the purpose of this research, disenfranchised is defined as atrisk of leaving school prior to high school completion due to personal difficulties resulting from environmental conditions (such as poverty, family difficulties, drug addiction, and violent communities).
\end{abstract}

\section{Introduction}

A growing scholarly literature is emerging that pays increased attention to disenfranchised students in many locations and learning environments. This scholarship acknowledges a rise in poverty rates in industrialized nations beginning in the 1970s. In Canada, one in eight school-aged children lives in a family with very low income (Canadian Council on Social Development, 2006; Yalnizyan, 2000). Market incomes have dipped below 1981 levels in a political climate of cuts to taxation and spending on social programs leaving families more reliant on market forces (Lawrence, 2001). These economic and social changes have very real effects on disenfranchised urban youth in schools. There is a small but growing body of literature aimed at addressing ways to meet learning needs of disenfranchised students. Student centered approaches and emphasis on staff-student relationships enhance motivation and learning for these students (Atkins, Bullis \& Todis, 2005; Housego, 1999; Wilkins, 2008). A school's caring environment contributes to the provision of an equitable education and student ability to achieve success (Kim \& Taylor, 2008). Listening to students, building trust, and understanding and incorporating personal circumstances into learning strategies are key elements of meeting the learning needs of disenfranchised students (Wishart, 2009).

International comparative approaches can add to the literature on schooling for disenfranchised students. The processes of globalization have been viewed as a threat to the contribution of qualitative research in education. However, given the vital role of culture in mediating global policies there is a growing interest in incorporating qualitative

Journal of Contemporary Issues in Education, 2012, 7(2), pp. 4-15

ISSN 1718-4770 (C) 2012 University of Alberta

http://ejournals.library.ualberta.ca/index.php/JCIE 
research in policy development (Vulliamy, 2004). This paper aims to contribute to policy development in education in both Spain and Canada.

The purpose of our research was to elicit the perceptions of humanities educators in Spain and in Canada regarding enhancing opportunities to retain disenfranchised students in secondary schools. For the purpose of this research, disenfranchised is defined as at-risk of leaving school prior to high school completion due to personal difficulties resulting from poverty, family difficulties, drug addiction, violent communities, and other related factors.

Educators in this research are based at university locations in Canada and Spain. Sites chosen for this research are located in Edmonton, Alberta, Canada and Madrid, Barcelona and Valencia in Spain. We explore the question: what do humanities educators understand regarding the effectiveness of pedagogical approaches designed to increase the engagement and retention of disenfranchised urban youth? Additionally we examine the similarities and differences in pedagogical approaches in both locations.

\section{Implications for Policy}

Brown (1990) identified a universal approach as the first wave in the sociohistorical development of schooling in much of the western world. In recent years public schooling has moved away from mass schooling which was arguably more effective for disenfranchised urban youth. Greater school choice, indicative of a move to conform to the wealth and wishes of parents (Brown, 1990) can be seen in current provincial initiatives in Alberta. Disenfranchised urban students often do not have the social and financial circumstances to choose specialized programs and are often squeezed out of these schools. Many turn to alternative programs, often a step toward leaving the school system prior to high school completion.

The causes of early school leaving are however, complex and multi-faceted (Alberta Education, 2001). Questions surrounding educational practices best suited to increasing high school completion rates have been prevalent in policy discussions in recent years in Alberta. Educational policy in Alberta addresses this question through policy documents - Removing barriers to high school completion (Alberta Learning, 2001) and First Nations, Metis and Inuit education policy framework (Alberta Learning, 2002). These documents are representative of a larger public discourse surrounding the need to remove barriers to high school completion for all students, and form part of the research analysis.

In Spain, where public education is organized nationally, some teacher education programs include approaches aimed at enhancing motivation and students' retention in schools. The Universidad Politécnica de Calalunya (UPC), in Barcelona, is responsible for the education of the Education and Research Staff (PDI, Personal Docente y de Investigación); the improvement of its academic activity; and, the delivery of the Masters degree in high school teacher education. Additionally, the UPC offers an after-degree in High School Technology Teaching Education, and activities on continuing professional development of the Compulsory (Junior) High-School Education, High School (non compulsory) and ongoing professional development. 
Both research contexts indicate a need to move to individualized approaches for this population of students. This research aims to contribute to policy discussions regarding best practices for early school leavers and teacher education.

\section{The Research Study}

Sites chosen for this research are located in Edmonton, Alberta, Canada and in Madrid, Barcelona and Valencia in Spain. University faculties and departments of education were chosen based on the relevancy of their work in education with disenfranchised high school students. Selective sampling was used in order to focus interviews on individuals with particular expertise on the topic and individuals who work in cooperation with colleagues engaged in similar work.

Both researchers have prior experience teaching in secondary school classrooms with student populations of disenfranchised youth. These experiences inform research interests and directions. The Alberta component of this research involves study of policy and practice of early school leavers who have been re-engaged in alternative schooling. Included in this research are case study, document analysis and reflections on current practice in teacher education.

In Canada, education is a provincial responsibility; therefore there is no national coordination of education programs to increase high school completion of students who have left high school prior to completion. In Alberta, alternative programs are designed to meet the educational needs of these students. Alternative programs exist in the public education system as store-front and charter schools, in the private system, and as nonformal educational programs. Enrolments in these schools are increasing.

In Spain, there is a national education program relevant to at-risk youth education, the PCPI, Programa de Cualificación Profesional Inicial (Initial Professional Qualification Program). The PCPI, is an alternative program for those students who did not graduate within the Spanish educational system in the compulsory high school program (ESO) and it offers a professional (trade) certification with the opportunity to acquire the secondary-level degree. The PCPI is designed to facilitate the students' employability but also their continuation in their optional senior high school education. The PCPI's predecessor, the Social Security Program, PGS (Programa de Garantía Social), which, in spite of its lack of credentialization, (offered no compulsory highschool degree), also provided valuable educational opportunities for those students at risk of dropping out of the regular program.

This study includes the experiences of educators who are working in higher education contexts, reflecting on their involvement with programs that are designed for secondary students who are at-risk of not completing high school. Consistent with a constructionist tradition this study incorporated the assumptions of an emerging design, a context dependent inquiry, and an inductive data analysis (Creswell, 2008). The study is bounded by the research time-frame of the approved ethics report. All interviews were conducted between August 2010 and October 2011. Consistent with case study design we conducted semi-structured interviews of six Spanish educators and two Canadian educators. A follow-up questionnaire was sent to the Spanish participants. Additionally, document analysis was included in the Alberta portion of the study. 
Drawing on LeCompte's (2000) explanation of selectivity, we used formative critical theory to guide our data collection and analysis. We used a qualitative comparative analysis to look for similarities and differences across cases (Leech \& Onwuegbuzie, 2008).

\section{Critical Theory}

Critical theory was first introduced by Horkheimer and the Frankfurt School theorists and served to demarcate an alternative to positivistic and technocratic approaches to social science philosophy (Brenner, 2009). A critical social theory offers a way to bring together multiple beliefs about human understanding, the nature of change, and the role of education in society (Freeman \& Vasconcelos, 2010). The context of a particular social group also needs to be assessed in order to resolve a specific issue such as high school completion. Critical theory is a participatory approach that engages stakeholders in a reflective reassessment of the relationships between overarching social, economic or political systems, and everyday practices, many of them unjust. Critical social theory offers a historical framework that challenges the theoretical or ideological underpinnings of everyday practices to develop new ways of conceiving of meaning and purpose in society (Lather, 1986). Our research sought to find alternative practices for disenfranchised students by seeking multiple understandings across research contexts.

Brenner (2009) notes critical theory is reflexive and oriented toward specific historical conditions and contexts. Critical theorists engage with normative questions through a dialectical relationship with the realm of practice. Change in social formation needs to come about through practice. Critical pedagogy offers ways to think about social reality that are liberatory; a way to approach education, through dialogue and reflection, whereby power relations can be interrogated and the needs of students met (Freire, 1996; Giroux, 2001).

A critical theory informs our research question aimed at improving educational opportunities for disenfranchised urban youth. Learning and listening are crucial to understanding "the lived details of the people connected to the practice or program" (Freeman \& Vasconcelos, 2010, p. 14). A critical pedagogical approach that moves beyond a vision of utopia and looks for a renewal of social relationships, questioning, and dialogue (Biesta, 1998; Schwandt, 2002) informs our research.

\section{Themes}

Data in this research was analyzed through an interpretivist lens to distill the following themes: tension between theory and practice; labeling of students; relationships with students; and, assessment.

\section{Tensions of Theory and Practice}

In both Spanish and Canadian contexts, educators experienced tensions between the ideals of critical practice and the daily realities of implementation. In Spain, research participants noted the rigidity of curricular expectations that appear to limit flexibility and pedagogic innovation. A Spanish program called Curricular Diversification (DC) adapts 
the curriculum to facilitate the learning of those students with learning difficulties. However, by decreasing the academic expectations of students a Pygmalion effect (Rosenthal \& Jacobson, 1992) was experienced. Teacher expectations were lowered and these expectations communicated to students through lower standards, resulting in lower academic achievement.

In Alberta, informal streaming happens through the provision of school choice programs. Choice programs, such as art, drama or sports tend to favour the interests of more privileged parents and students. Students who are deemed 'at-risk' of leaving public schools prior to high school completion are provided greater flexibility through outreach programs and vocationally oriented choices resulting in lower academic expectations (Wishart, Taylor \& Shultz, 2006). However, some alternative programs utilize arts based programming as a basis for critical practice (Dalgetty \& Cloutier, 2000). Additionally, these programs offer a range of academic courses leading to high school completion for disenfranchised students.

Wishart (2009), when teaching in an alternative school that incorporated a critical pedagogical practice, identified a tension between the philosophical beliefs of the school and the need to follow the Alberta curriculum and function within the structures of formal schooling. Additionally, her study noted a lack of understanding of these philosophical beliefs and alternative pedagogies on the part of beginning teachers. Teacher education programs prepared teachers for the public school system but did little to prepare teachers for a disenfranchised student population. Teaching in alternative programs with disenfranchised students then requires learning anew. This learning is often complicated by resistance based on a preconceived notion of what a teacher should be, a role defined by Giroux (1988) as "managing and implementing curricular programs rather than developing or critically appropriating curricula to fit specific pedagogical concerns" ( $\mathrm{p}$. 122). This type of approach tends to result in disenfranchised students falling through the cracks.

The arts and humanities offer ways to engage students who do not connect with traditional pedagogy. Prentki and Selman (2000) note drama offers a variety of contributions to critical literacy pedagogy. While there are many opportunities for critical engagement, both teachers and students need to be prepared for the process. Teachers need to come to an understanding of popular theatre as "a process of theater which deeply involves specific communities in identifying issues of concern, analyzing current conditions and causes of a situation, identifying points of change, and analyzing how change could happen" (Prentki \& Selman, 2000, p. 8). Students need comfort and trust, vital components of community building in the popular theater process. Dalgetty and Cloutier (2000), using popular theatre, helped youth to understand "the importance of education and its role in breaking the cycle of poverty and violence" (Dalgetty \& Cloutier, 2000, p. 42) that was hindering their educational development.

\section{Labeling}

In both Spanish and Albertan contexts research participants noted the difficulties for students, of being labeled as differentiated in some ways from the mainstream student population. In Alberta, disenfranchised students share common public schooling experiences in which their thoughts, beliefs, and perspectives are rejected by interlocking 
systems of oppression (Wishart, 2009). This study noted that in public schools these students were rejected because of integrations of poverty, race and gender. Lack of social acceptance had a significant impact on students' beliefs about themselves. Wishart, Taylor and Shultz (2006) explain that disenfranchised students have occupied lower education streams throughout most of their schooling years. Attempts through alternative programs, to provide equal opportunities for these students are thwarted by the students' beliefs about themselves as additionally lacking because they do not attend regular public schools. These students have, to a large extent, internalized labels applied to them by experts, teachers and peers in previous schools.

Ultimately there is need to move toward a critical literacy pedagogy that requires a level of analysis based on a critical evaluation of students' personal experiences (Wishart, 2009). Our research concurs that through a critical literacy both students and teachers begin to understand the institutional and community conditions that have contributed to lack of academic success. In this process students begin to alter beliefs about themselves. There is a need to understand how students' experiences of being labeled and judgments made about them by teachers shape individual subjectivities. Shor (1999) notes the categories we place youth into are themselves social constructs. These categories grow out of value-laden assumptions about how youth should behave. The ways we speak and are spoken to help shape us into the people we become (Shor, 1999) and youth who are labeled in schools are no exception.

A critical approach, that considers students' beliefs about themselves, can be incorporated into academic courses as well. In the humanities, Social Studies provides an example. As Knoblauch and Brannon (1993) remind us, critical teaching is situated "within circumstances of 'normal' educational practice" (p. 75). Wishart (2009) incorporated critical issues such a 'police brutality' into historical discussions in a grade 11 Social Studies classroom. The historicity of issues can be used as a tool to cut through "pedagogical practices that pen in rather than liberate consciousness" (Zandy, 2000, p. 147). In classrooms, language holds power to name experiences in particular ways that benefit some students and marginalize others. Choosing topics for classroom discussion that are relevant to middle class, mainstream students and avoiding topics that come out of the lives of disenfranchised students, privileges some while marginalizing others. Bernstein (1977) explains that, "structural relationships, implicitly and explicitly, carry the power and control messages and shape, in part, the forms of response to them" ( $p$. 155). If we are to empower disenfranchised students to change their experiences, in response to issues such as police brutality we have to incorporate these issues in ways that that are non-judgmental while addressing the complexity of the issue.

\section{Relationships}

In Spain, the PCPI, the alternative program for non-graduating students within the Spanish educational system offers an effective response to preventing early school leaving by providing more individualized attention for academic learning. While increased individualized attention from teachers has been recognized as effective for disenfranchised students (De La Ossa, 2005), increased attention to alternative pedagogies could enhance completion rates. Nevertheless, alternative pedagogies may 
become vulnerable to constrains within the educational system, as appears to be the case in the Spanish PCPI program. Research participants in the PCPI noted alternative pedagogies are likely to be sacrificed to curricular expectations.

Students in alternative programs in Alberta voice similar insights about the importance of individual attention from teachers (Alberta Learning, 2001). Students identify the significance of one-on-one help with schoolwork and having a positive relationship with teachers (De La Ossa, 2005; Wishart, 2009). Research participants in both Alberta and Spain identified smaller class sizes as important in enabling increased attention from teachers.

Initial relations with disenfranchised students need to focus on ensuring a safe and welcoming environment while beginning to build respectful relationships (Wishart, 2009). Trust is built slowly. As O'Dowd (1993) explains, many of these students have received very little trust and love and may need more time to develop positive relationships. Teachers too need time to understand the struggles of building relationships with disenfranchised students. Understanding of the specialized student population is essential if teachers are to keep working at building these difficult relationships.

As these relationships are extended and deepened students come to see the school as a place where they belong. Successful programs for students who have left mainstream schools are ones to which students have a sense of ownership (O'Dowd, 1993). This begins by giving students a voice. Alberta Learning (2001) acknowledges the importance of listening to and supporting disenfranchised students who are dealing with complex problems in their lives.

Alberta Learning (2001) also notes the importance of trust and belonging. Popular theatre provides an example. Boal (1985) suggests there is not only a need to feel comfortable with participation but there is also a need to develop knowledge, control and expressiveness of one's body. In order for students to feel comfortable in this process, a community must first be established. This is a community of individuals who have shared experiences of marginalization in schools. Freire (1996) suggests embracing notions of participant ownership and exchange of ideas while engaging in reflection and action. Strong relationships and feelings of trust and belonging are necessary precursors to critical practice.

\section{Assessment}

There is a tension inherent in a shift from an initial focus on positive interactions to more in-depth relationships. Schools by design must assess students. In the Spanish context, educators note that programs for disenfranchised students need to consider alternative evaluation approaches. However, higher curricular expectations have led to less flexibility to explore alternative formative assessments. Students who have had difficulty in the regular program will continue to have difficulty in alternative programs that use traditional pedagogies and assessment methods. However, these traditional methodological approaches are not mandated. Teachers have the flexibility to explore alternative methods and may do so in response to declining enrolments.

In Alberta, high school completion is also the expectation and goal for all students. While some alternative programs continue to struggle with traditional teaching

methods and definitions of success for disenfranchised students, some are also exploring 
critical pedagogies and assessment methods. Wishart (2006) discusses this approach as a process that often takes much longer for students who are disenfranchised. Many begin in programs designed to bring young people in off the streets, move them into informal schooling and provide supports, then eventually into formal schooling and high school completion. Many students start and stop this process a number of times, so flexibility in programming is important.

While this current study also found traditional assessment methods to be problematic for disenfranchised students, literature on defining success for these students is lacking. Success is ultimately measured as high school completion and results on diploma exams. For disenfranchised students, small, incremental degrees of success happen in drama and in literacy programs that then become important building blocks for academic success. Dalgetty and Cloutier (2000) note that after using popular theater to understand social issues that had blocked their development youth saw the importance of education and its role in breaking the cycle of poverty and violence.

Alberta Learning (2001) acknowledged the importance of listening to and supporting students who are dealing with complex issues in their lives. However, Alberta Learning did not recognize the importance of greater flexibility in attendance, and providing additional resources to help students' complete high school. With Alberta Learning focusing on academic achievement as the measure of success, it is not surprising that schools continue to avoid examining process as a way to gauge progress (Wishart, 2009).

However, similar to the acknowledgement of Alberta Learning, educators in the Spanish program PCPI recognize the inadequacy of at-risk student assessment that focuses on academic skills without taking into consideration the personal context of those students.

\section{Discussion}

Educators in both Spanish and Canadian educational contexts recognize the importance of critical pedagogical practices for disenfranchised urban students. There are some notable differences in practice between these two research sites. In Spain, alternative education programs for disenfranchised high school students focus on professional trade certification with an option to complete high school. One problem with this program has resulted from a more rigid curriculum resulting in teachers being more constrained in their capacity to implement flexible pedagogy. Students who had difficulty in the regular program are now being taught with traditional pedagogies that have proven unsuccessful in students' past educational experiences.

Program choices are much more fragmented in Alberta. Students are sorted into different school programs based on academic merit. An analysis of these streams highlights the over representation of historically disadvantaged groups in lower academic streams (Wishart, Taylor \& Shultz, 2006). Vocational programs have grown in recent years in response to labour shortages. These programs tend to be inferior versions of academic curricula rather than being based on technical knowledge. The dead end nature of lower stream courses is highlighted by the fact that they are often provided only in the first two years of high school (Alberta Learning, 2001). Alternative programs outside of the public system attempt to address this lack. 
In Alberta, very little is being done to recognize and explore the tension between theories of education for disenfranchised students and the traditional practices in public school classrooms. Similar to the Spanish educational system, curriculum addresses objectives, content, and evaluation. Teachers can make autonomous decisions regarding teaching methodology. In Spanish contexts, this flexibility often means teachers fall back on traditional teaching methods that appear not to work well with disenfranchised students. Alberta curriculum identifies skills and processes including inquiry, problem solving and critical thinking providing opportunities for flexibility in pedagogy and learning strategies. However, the inclusion of critical literacy approaches is rare.

In the Spanish context, it was noted that students who have had previous discouraging and inadequate educational experiences could complete their education with the assistance of teachers who demonstrate affection to them and who help them to develop capacity to plan and learn. Given that the pedagogy used in the classes is in general traditional, characterized by lecturing, studying from textbooks, written drills, and rote learning, the attention to teacher-student relationships is minimal. In Alberta, with a varied approach to school practices, there is a tension between traditional and social justice approaches. A social justice approach includes a growing recognition of the need to build relationships with disenfranchised students, yet the need to prepare students for standardized tests and grade completion is a priority.

There are adaptations to the regular program in Spain, including modifications such as flexible groups that organize the student's progress and that are based on the student's capacities and skills. However, it is difficult to find a balance between equity and quality. An equitable approach would mean greater flexibility and individualized modifications for disenfranchised students. However, often these modifications result in lower quality programs. In Alberta, special needs coding can be applied in order to achieve program modifications. This practice further complicates the results of labeling of disenfranchised students. As in the Spanish context, the practice struggles between equity and quality by recognizing the need to provide greater resources for these students. The resultant labeling often means the expectations for academic achievement are lowered.

Study participants in Spain were optimistic about recent program initiatives that were implemented with objectives of teaching students who have had difficulties in traditional classrooms. One of these programs is project-based. These programs tend to modify behaviors effectively in that students show interest in the subject material, attend classes regularly, work with enthusiasm and end up completing the program. However, in order for these programs to work well in the long term, participants felt they should be integrated into the mainstream educational system.

Assessment of disenfranchised students that focuses on academic skills and fails to take into consideration the personal context of students' lives outside of school will prove difficult for these students. This practice continues in both research contexts. It is likely that students from disadvantaged social classes who have social difficulties end up abandoning high school. Life experiences such as hunger, sleeplessness, functional illiteracy, drug addiction, abuse, and devaluing of school prevent disenfranchised students from reaching schooling objectives. 


\section{Epilogue}

As we conducted this study, we recognized our involvement in the research was guided by our earlier teaching of disenfranchised students in an alternative educational program. These experiences affected our selection and assessment of programs as we feel strongly that critical pedagogical approaches are an important contribution to meeting the learning needs of students at-risk of leaving school prior to high school completion. We acknowledge a growing interest and understanding of the role educators can and do play in the schooling experiences of these youth. With more educators hoping to make a difference for all students, we hope this comparative analysis offers some hopeful approaches. 


\section{References}

Alberta Learning. (2001). Removing barriers to high school completion - Final report. Edmonton, AB.

Alberta Learning. (2002). First Nations, Metis and Inuit education policy framework. Edmonton, AB.

Atkins, T., Bullis, M., \& Todis, B. (2005). Converging and diverging service delivery systems in alternative education programs for disabled and non-disabled youth involved in the juvenile justice system. Journal of Correctional Education, 56(3), 253-286. Retrieved from http://login.ezproxy.library.ualberta.ca/login?url=http://proquest.umi.com/pqdweb ?did=908579441\&Fmt=7\&clientId=12301\&RQT=309\&VName=PQD

Bernstein, (1977). Class, codes and control (Vol. 3). London, UK: Routledge.

Biesta, G.J. (1998). Say you want a revolution... Suggestions for the impossible future of critical pedagogy. Educational Theory, 48(4), 499-510.

Boal, A. (1985). Theater of the oppressed. New York: Theater Communications Group.

Brenner, N. (2009). What is critical urban theory? City, 13(2-3), 198-207. DOI: $10.1080 / 13604810902996466$

Brown, P. (1990). The 'Third wave': Education and the ideology of parentocracy. British Journal of Sociology of Education 11(1), 65-85.

Canadian Council on Social Development. (2006). The progress of Canada's children 2006. http://www.ccsd.ca/pccy/2006/index.htm

Dalgetty, A., \& Cloutier, J. (2000). Popular theater, cultural awareness and solidarity: Canada to Nicaragua. In T. Prentki \& J. Selman (Eds.). Popular theater in political culture. (pp. 42-47). Portland, OR: Intellect Books.

De La Ossa, P. (2005). "Hear my voice:” Alternative high school students' perceptions and implications for school change. American Secondary Education, 34(1), 24-39.

Freeman, M., \& Vasconcelos, E.F.S. (2010). Critical social theory: Core tenets, inherent issues. In M. Freeman (Ed.). Critical social theory and evaluation practice. New Directions for Evaluation, 127, 7-19. DOI: 10.1002/ev.335

Freire, P. (1996). Pedagogy of the oppressed. New York: Continuum.

Giroux, H. A. (1988). Teachers as intellectuals: Toward a pedagogy of learning. Westport, CT: Bergin \& Garvey Publishers, Inc.

Giroux, H. A. (2001). Theory and resistance in education: Toward a pedagogy for the opposition. Westport, CA: Bergin \& Garvey.

Housego, B. E. (1999). Outreach schools: An educational innovation. Alberta Journal of Educational Research, 45(1), 85-99. Retrieved from http://login.ezproxy.library.ualberta.ca/login?url=http://proquest.umi.com/pqdweb ?did=413123781\&Fmt=7\&clientId=12301\&RQT=309\&VName=PQD

Kim, J., \& Taylor, K. (2008). Rethinking alternative education to break the cycle of educational inequality and inequity. The Journal of Educational Research, 101(4), 207-220. Retrieved from http://login.ezproxy.library.ualberta.ca/login?url=http://proquest.umi.com/pqdweb

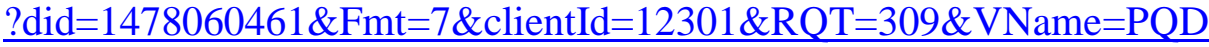


Knoblauch, C.H., \& Brannon, L. (1993). Critical teaching and the idea of literacy. Portsmouth, NH: Boynton/Cook Publishers.

Lather, P. (1986). Research as praxis. Harvard Educational Review, 56(3), 257-276.

Lawrence, P. (2001). Advantage for whom? Edmonton, AB: Parkland Institute.

LeCompte, M. D. (2000). Analyzing qualitative data. Theory into practice, 39(3). 146154.

Leech, N.L., \& Onwuegbuzie, A. J. (2008). Qualitative data analysis: A compendium of techniques and a framework for selection for school psychology research and beyond. School Psychology Quarterly, 23(4), 587-604.

O'Dowd, M. (1993). Re-visioning empowerment with the research subject and the 'at-risk'. In L. Angus (Ed.). Education, inequality and social identity. (pp. 21-56). Washington, DC: The Falmer Press.

Prentki, T., \& Selman, J. (2000). Popular theater in political culture: Britain and Canada in focus. Portland, OR: Intellect.

Rosenthal, R., \& Jacobson, L. (1992). Pygmalion in the classroom: Teacher expectation and pupils' intellectual development. Irvington publishers: New York.

Schwandt, T.A. (2002). Evaluation practice reconsidered. New York: Peter Lang.

Shor, I. (1999). What is critical literacy? In I. Shor \& C. Pari (Eds.). Critical literacy in action: Writing words, changing worlds. (pp. 1-30). Portsmouth, NH: Boynton/Cook Publishers, Inc.

Wilkins, J. (2008). School characteristics that influence student attendance: Experiences of students in a school avoidance program. The High School Journal, 91(3), 1225. Retrieved from http://login.ezproxy.library.ualberta.ca/login?url=http://proquest.umi.com/pqdweb ?did=1444298621\&Fmt=7\&clientId=12301\&RQT=309\&VName=PQD

Wishart, D., Taylor, A., \& Shultz, L. (2006), The construction and production of youth "at-risk". Journal of Education Policy, 21(3), 291-304.

Wishart, D. (2009). The rose that grew from concrete: Teaching and learning with disenfranchised youth. Edmonton, AB: The University of Alberta Press.

Vulliamy, G. (2004). The impact of globalization on qualitative research in comparative and international education. Compare, 34(3), 261-284.

Yalnizyan, A. (2000). Canada's great divide: The politics of the growing gap between rich and poor in the 1990s. Toronto, ON: Centre for Social Justice.

Zandy, J. (2000). Human labor and literature. In I Shor \& C. Pari (Eds.). Education is politics: Critical teaching across differences, postsecondary. (pp. 145-159). Portsmouth, NH: Boynton/Cook Publishers, Inc. 